\title{
GLOBALIZATION AND EUROPEANIZATION: ANALYSING CHANGE
}

Stella Ladi

$2006 / 4$

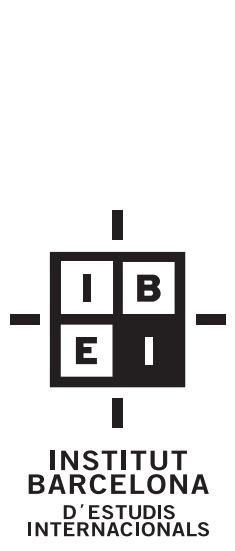

Stella Ladi

Advisor on European Issues at the Ministry of the Aegean and of Island Policy, Greece and Honorary Research Fellow at Sheffield University, UK

sladi@ypai.gr 


\section{IBEI WORKING PAPERS}

$2006 / 4$

Globalization and Europeanization: Analysing Change

(C) Stella Ladi

(C) IBEI, de esta edición

Edita: $\quad$ CIDOB edicions

Elisabets, 12

08001 Barcelona

Tel. 933026495

Fax. 933022118

E-mail: publicaciones@cidob.org

URL: www.cidob.org

Depósito legal: B-21.147-2006

ISSN:1886-2802

Imprime: Cargraphics S.A.

Barcelona, December 2006 


\title{
GLOBALIZATION AND EUROPEANIZATION: ANALYSING CHANGE
}

\author{
Stella Ladi
}

\begin{abstract}
The main motivation for exploring the relationship between globalization and Europeanization is the understanding of the importance of exogenous factors for policy change at the domestic level. Can we distinguish the impact of Europeanization to that of globalization? What is the relationship between globalization and Europeanization and what can we learn about the impact of the two phenomena upon political institutions, public policies, identities and values of EU member-states? Can we distinguish the traces of globalization to those of Europeanization upon the domestic level? The paper draws upon International Relations and International Political Economy theories of globalization as well as upon the Europeanization literature. Both phenomena are multi-dimensional and in order to assess their impact and their relationship three dimensions are explored: political institutions, public policies and values and identities. It is concluded that the two phenomena are interwoven and that there is no antithetical relationship between them. Their core is similar, based on the values of neo-liberalism, representative democracy and open market economy.
\end{abstract}

Key words: Globalization, Europeanization, Change, Policies, Institutions, Identities 


\section{Introduction}

The changes that have taken place in the way markets function, the facilitation and the rapidity of communications and the new modes of governance that extend outside the national borders have steered a vivid discussion on globalization and its implications for the state. The concept is multidimensional and its magnitude as well as its intensity are disputed. All social sciences have dealt with globalization and its dimensions and the central question is how it affects the state, its institutions, its public policies and the identity and dominant values of its citizens. An important characteristic of globalization is the existence of international and regional organizations that are responsible for an increasing number of aspects of public life. The European Union (EU) can easily be considered as the most developed regional organization with an influence that extends outside its geographical borders. What is the relationship between these two powerful phenomena, globalization and Europeanization, and how are the EU member-states affected by them? Are the two phenomena different or are they both expressions of neo-liberalism, representative democracy and of open market economy?

The aim of this paper is to explore the relationship between globalization and Europeanization through the analysis of the impact of the two phenomena on EU member-states and to contribute to the growing literature on the topic (e.g. Levi-Faur, 2004, Rosamond, 1999, Verdier and Breen, 2001, Wincott, 1999, Wallace, 2000). First, the terms are defined, the existing literature is discussed and its strengths, weaknesses and gaps are outlined. A framework of analysis of the relationship between the two phenomena is developed. The second section of the paper, applies the framework of analysis by discussing the impact of globalization and Europeanization upon: political institutions, public policies, values and identities within member-states. This three-dimensional approach, illustrated with examples from across Europe, attempts to offer a holistic framework of analysis of the two phenomena. The advantage of such an approach is that it makes the comparison between different outcomes more concrete and it allows for the observation of variations in the pace and depth of change between political institutions, public policies and values and identities.

\section{Globalization and Europeanization: A Contested Relationship}

The main motivation in exploring the relationship between globalization and Europeanization is to understand the way external factors affect the political institutions, public policies, values and identities of states. The way globalization affects Europeanization and vice versa is also an interesting question that can be answered either through the lens of international political economy or through the study of their outcomes which can be translated as the changes that take place at the domestic level. The focus of this paper is nearer this second stream of thought. In this section, first the terms globalization and Europeanization are defined and then the literature that attempts to link the two phenomena is discussed in order to develop a framework of analysis of the relationship between the two phenomena. The main argument advanced here is that the impact of the two phenomena should be apparent in political institutions, public policies and values and identities. 


\subsection{Globalization: A Process or just a Concept?}

The discussion about the impact of 'globalization' upon domestic politics has started in the International Relations discipline long before the discovery of the term globalization (e.g. Gourevitch, 1978, Milner, 1985). Gourevitch's (1978) second image reversed argument is the first time that emphasis is placed upon the two way process of internationalization. It is claimed that international relations and domestic politics are so interrelated that they should be analyzed simultaneously. "The international system is not only a consequence of domestic politics and structures but a cause of them" (Gourevitch, 1978: 911). Today, the discussion continues in the same vein although there is a qualitative difference in the reversibility of the argument: "Domestic politics and structures are not only a consequence of the international system but a cause of it".

Globalization is a complex concept that has been used in the whole range of social sciences, a fact that makes its meaning often unclear and leads to accusations for emptiness. As it is the case with broad terms such as globalization there is no one definition attached to it. The first wave of theories on globalization describes the weakening of the state and its replacement from new modes of governance of human society (e.g. Held, 1991, Ohmae, 1990, Strange, 1996). The second wave of theories emerged as a reaction to the excessive predictions of the first wave writers. They claimed that nothing new is happening and that the sovereignty of the state remains the same (e.g. Harman, 1996 and Hirst and Thompson, 1999). Another argument following the same logic is that the changes that are observed are not due to globalization but due to regional integration which manifests itself in the strengthening of organizations such as the EU (Anderson, 1995). Finally, the third wave of writers takes a midway position and supports the idea that the sovereignty of the state is not decreasing but that its functions and structures are changing within a more internationalized world (e.g. Cerny, 1996: 617-37).

The third approach is the most interesting because it recognises the multidimensional nature of globalization encapsulating both its material and ideational nature and impact. The writers of the third approach emphasise the reversibility of globalization and describe it as a process in progress where a large number of governmental and non-governmental agents plays an important role within the system of global governance (e.g. Higgott, 1999: 24-36). Two are the implications of this approach. First, the state is studied as an agent of equal analytical importance to other agents that adapt to the new conditions but at the same time influence the direction of globalization (Scholte, 2005). Second, globalization is understood as a multi-dimensional approach where equal emphasis should be placed to its political, economic and cultural dimensions (Hay and Marsh, 1999: 5-22).

There are three aspects of the discussion on globalization that are interesting for this article. First, the questioning of the hypothesis that one and only one ideological system exists, following Fukuyama's (1992) prediction about the end of history. Such an assumption would signify that globalization and Europeanization are two aspects of the same coin. Second, the examination of the prevalence of new modes of governance. Such an acceptance would show an agreement that there is a global process of substantial institutional and political reform in place. Third, the exploration of the different approaches about the relationship between globalization and regional organizations such as the EU. What follows is a discussion of the theoretical and ideological paths that have been developed for the understanding of the impact of globalization and consist the framework for the empirical research on the question. 
The views of the different political traditions upon these three issues have been successfully classified by Held and McGrew (2002) as follows. Neo-liberals start from the position that the political as well as the economic life of citizens are issues of personal liberty and initiative and as a result the state should have as few responsibilities as possible (e.g. Hayek, 1976 and Kegan and Ohmae, 1990). The market is what determines governments' route towards Western liberal democracy which is the dominant ideological system. Given that globalization is a predetermined process the significance of regional organisations is of minimal importance. There is a second group of liberals that Held and McGrew call liberals internationalists who place more emphasis upon the significance of international co-operation and of international and regional organizations as a result of increased interdependence (e.g. Hinsley, 1986). For them, it is important to support regional organizations such as the EU because it is a step towards further international co-operation. They agree with the neo-liberals that the route is predetermined and it leads to Western liberal democracy.

A related school of thought is that of institutional reforms which also starts by recognizing the necessity of international co-operation in order to overcome the shortcomings of the public sector (Kaul, Gurnberg and Stern: 1999). For them, strong regional organizations are welcomed because they signify a step towards deeper international co-operation. Held and others (1999) differentiate from the institutional reformists and classify themselves as supporters of global transformation. They are interested in the way processes of globalization could be better organized and they put forward the model of 'cosmopolitan democracy'. In their model co-exist different levels of governance, above, lower or parallel with the state and the citizens function as citizens of the world that have a common identity which translates itself to rights and duties at all of the above levels. Organisations such as the EU are desirable and constitute one of the levels of global governance. Both of these intermediate schools of thought agree that liberal democracy is the dominant system of governance but recognize the possibility of change through the use of democratic vote by the citizens.

The supporters of statism and of protectionism claim that the best way to confront the threats of globalization is to strengthen the state by looking at the example of East Asian countries (Leftwich, 2000). They disagree that liberal democracy is the only possible system and they are in favor of regional organizations as long as they increase the power of the state. Finally, the radicals support the development of new modes of governance that will be based on institutions of direct democracy, self-governing communities and the value of equality (Falk, 1995, Klein, 2000 and Callinicos, 2000). The two basic preconditions for the implementation of their proposals is the possibility of the existence of a variety of political systems different to liberal democracy. The EU is seen as an organization that promotes liberal democracy in a similar way to the International Monetary Fund (IMF) and to the World Trade Organisation (WTO) and that is why it is seen as closely linked to such organizations.

In summary, in the last fifteen years globalization has been in the centre of the analysis of all theoretical approaches. There is an agreement that liberalization is the main parameter of globalization. What differs is whether they are seen as an unchangeable parameter of globalization or as just one of the possible avenues for globalization. The understanding of the role of the EU also varies. For some, the EU and Europeanization is seen as a response to globalization (e.g. Leibfried, 2000). According to this point of view, a strong Europe can function as an obstacle to further liberalization and Americanization of the world. A diametrical opposite reading of the relationship is 
that the EU facilitates globalization because through its values it promotes Western liberal democracy (e.g. Rosamond, 1999). Finally, according to the third approach, the two phenomena are not entirely connected (e.g. Wincott, 1999). This third approach recognizes the dual nature of globalization, which is ideational and material as well as the reversibility of the phenomenon. What follows is the exploration of the concept of Europeanization.

\subsection{Europeanization: A Parallel Phenomenon?}

The impact of the EU is often described as Europeanization. The term made its first appearance in the 1990s (e.g. Ladrech, 1994) in order to describe a process different to European integration and to harmonisation that are concepts focusing on the domestic adjustment of the member states to EU obligations. Europeanization is a concept acknowledging the two-way process of policy change between the EU and domestic environments in contrast to terms such as European integration that are describing the one-way impact of the EU upon member-states (Featherstone, 2003). It has been defined as 'a process by which domestic policy areas become increasingly subject to European policy-making' (Boerzel, 1999: 574) or as 'the emergence and the development at the European level of distinct structures of governance' (Risse, Green Cowles and Caporaso, 2001: 1)

For Radaelli (2003: 30) Europeanization refers to:

Processes of (a) construction, (b) diffusion, and (c) institutionalisation of formal and informal rules, procedures, policy paradigms, styles, 'ways of doing things', and shared beliefs and norms which are first defined and consolidated in the making of EU public policy and politics and then incorporated in the logic of domestic discourse, identities, political structures, and public policies.

Radaelli's definition of Europeanization is useful for three reasons: first, it sees Europeanisation as a process of institutional and policy change that takes place at both the European and national levels although it can be criticised for not acknowledging the importance of the two way process of Europeanization. Second, it emphasises the importance of policy transfer and of diffusion and third it leads us to a broad definition of policy change. Policy change can be traced at the domestic discourses, identities, political structures and public policies and it is the result of the institutionalisation of formal and informal rules, procedures, policy paradigms, styles and shared beliefs and norms.

The operationalization of definitions of Europeanization in the study of its impact upon member-states has largely followed a historical institutionalist approach. Risse, Green Cowles and Caporaso (2001) adopt a three steps top-down approach, where they first look at the changes at the European level, they continue with the adaptational pressures for change and finally, they confront the domestic mediating factors. Schmidt (2002) and Knill (2001) in an attempt to be more analytical about what happens at the European level start by analysing the mechanisms of Europeanization. Ladi (2005b) applies a different three steps approach that distinguishes between 'soft' and 'hard' mechanisms of Europeanization, continues with the analysis of the mediating factors of change and concludes with the possible outcomes of Europeanization. Having defined globalization and Europeanization, the next section aims to the development of a framework of analysis of the relationship between the two as far as it concerns their impact upon domestic politics. 


\subsection{Analysing the Relationship between Europeanization and Globalization}

The analysis of the relationship between Europeanization and globalization is not an easy task. Both of the phenomena are multi-dimensional and their definitions are often abstract and general. They are concepts that refer to the macro-level of the analysis which makes any attempt to correlate them, quite theoretical. This paper attempts to limit the spectrum by focussing on the relationship of globalization and Europeanization as far as it concerns their impact upon EU member-states. The main question of the paper is whether we can distinguish the impact of Europeanization to that of globalization. An answer to this question will allow us to understand a lot about the relationship between the two phenomena.

In the last few years there have been a few but very interesting attempts to discuss the relationship between the two phenomena. There is an agreement that globalization and Europeanization are closely related, but there are variations in the perceptions of the degree of integration of the two phenomena. One approach claims that Europeanization is a 'filter' for globalization (Wallace, 2000) or in an even stronger language, an 'antidote' to globalization (Graziano, 2003). Europeanization as a 'filter' for globalization signifies the capacity of the EU for deep co-operation on issues of political economy, but also on other issues, which allows for a selective reaction to the pressures of globalization (Wallace, 2000). Europeanization as an 'antidote' of globalization, moves a step forward and refers to the capacity of Europeanization not only to act as a filter for the pressures of globalization but also to promote policies and institutions that affect the same processes of globalization towards a more socially just developments. Graziano (2003) wonders whether in a few years we will be able to talk about the 'Europeanization of globalization'. What is characteristic of this approach is that the EU is seen as mediating between the state and globalization, which means that it is not part of globalization but is external to it.

A diverse approach to the relationship between globalization and Europeanization, understands globalization as the main force that drives international change and sees Europeanization as simply following the trends outlined by globalization. This means that the main phenomenon that leads the way towards neo-liberalism is globalization and the EU is part of it. For example, Levi-Faur (2004) in a study of the liberalization of telecoms and electricity regimes of EU and non EU memberstates comes to the conclusion that Europeanization matters in a less obvious and less critical way than globalization. It is interesting to observe the equation between liberalization and globalization. This finding is confirmed by the study of the Spanish and Portuguese telecommunications and electricity sectors (Jordana, Levi-Faur and Puig, 2006). In the same vein Della Sala (2004) in his study of Italy and of the reforms that are taking place comes to the same conclusion. The argument goes that Europeanization plays an indirect role in the process of change and that there are other global pressures that are more prominent. Verdier and Breen (2001) apply a quantitative research design in four different domestic dimensions and observe that in areas such as labour market and capital market, it is globalization that is mainly responsible for change while in electoral competition and in centre-local government, the EU plays an important role.

A reverse argument which nevertheless is opposite to the idea of Europe as an 'antidote' of globalization is put forward by Scharpf (2002). In his study of the European Social Model he shows that if anything the European Union has limited the options of the member-states as far as their welfare- 
states are concerned to "supply-side strategies involving lower tax burdens, further deregulation and flexibilization of employment conditions, increasing wage differentiation and welfare cutbacks..." (Scharpf, 2002: 649). He further argues that the World Trade Organization (WTO) rules are less constraining which means that it is not globalization that limits the EU choices on social policy. Scharpf's argument could signify the 'Europeanization of globalization' but not as Graziano (2003) imagines it but rather as a further push towards liberalization. The analysis of all these authors is closer to the third wave of globalization theories that acknowledges the possibility of diverse effects in different policy areas. Also in this case, the liberal aspects of change are linked to globalization rather than Europeanization.

A variety of research designs is applied in the above studies. One approach is the study of the relationship of globalization and Europeanization by looking at one country specific case-study (Graziano, 2003 and Della Sala, 2004). The advantage of this approach is that in depth analysis is allowed and a lot of interesting empirical information is presented. The comparative potential of such design is limited unless is part of a larger project where case-studies from different countries, using the same parameters, exist. A second strategy is to select specific sectors or dimensions of domestic politics and to offer a comparative quantitative analysis of the changes that are taking place (Levi-Faur, 2004 and Verdier and Breen, 2001). The advantages and disadvantages, here, are reverse of the first approach. The strength of the second approach is its comparative richness while its weakness is the lack of depth of the data used, which results to a superficial reading of the national context. In the next section, a framework of analysis of the impact of exogenous factors upon the domestic level is proposed that could be applied to both quantitative and qualitative research designs.

\section{A Three-dimensional Approach to the Relationship between Globalization and Europeanization}

The aim of this paper is to provide a framework for analysis that can be useful for both quantitative and qualitative research. For this, an approach that is able to take into account the effects of globalization and Europeanization in three different dimensions of domestic politics is suggested: a) political institutions, b) public policies and c) values and identities. These three dimensions have been extracted from the definitions of globalization and Europeanization discussed in the previous sections as well as from the theories of structure and agency and new institutionalism. It is claimed that changes in these three dimensions have to be analysed in order to come to a conclusion about the impact of globalization and Europeanization and their relationship because both the mechanisms and the outcomes related to the change of each of these tree dimensions can differ substantially. It has already been shown that it is possible to observe changes in one dimension at a given time (Ladi, 2005a). An interesting question is whether globalization and/or Europeanization can provoke change in one dimension rather than another one. For example, could globalization affect values and identities more than political institutions? What can we learn about the relationship between globalization and Europeanization if such differences can be observed? 
The proposed approach has been informed by the structure and agency literature (Ladi, 2005a: 9-14), and in particular, by the dialectical approaches to structure and agency as well as by new institutionalism and by its application in the understanding of the impact of Europeanization upon domestic politics (Hall and Taylor, 1996, Boerzel and Risse, 2003). The dialectical approach of structure and agency, in order to explain change, places the emphasis upon the interaction between structures and agencies (e.g Giddens, 1984, Archer, 1985 and Mouzelis, 1995). Political institutions inform us about the structural dimension of change. Values and identities refer to the agency and public policy changes shed light to the interaction between structures and agencies. Observing change upon all three dimensions offers a holistic view of the impact of the two phenomena upon domestic politics.

Similarly, new institutionalism and especially the way it has been applied on Europeanization explores change upon policies, politics and polity (Boerzel and Risse, 2003). As it has been argued elsewhere, in order to understand change there are three steps that need to be analysed: the mechanisms, the mediating factors and the possible outcomes (Ladi, 2005b). There are 'soft' and 'hard' mechanisms of Europeanization and globalization depending on the level of coercion including institutional compliance, imitation, policy transfer, policy learning and diffusion (Knill, 2001, Page, 2003, Dolowitz and Marsh, 1996). The success and level of change varies depending on the national mediating factors that involve the economic vulnerability, political institutional capacity, policy legacies, policy preferences and discourse of the domestic level (Schmidt, 2002). Finally, the outcome of these processes can be convergence, divergence or inertia. We are interested in the mechanisms, mediating factors and outcomes related to the change of political institutions, public policies and values and identities. The focus though is not change per se but the relationship between Europeanization and globalization as it manifests itself through the study of change at the domestic level. In order to succeed this we explore the similarities and differences between the mechanisms that are in place as well as the possible outcomes. It is important to underline though that the outcomes are always on progress as there is no final end of globalization and Europeanization and determinism needs to be avoided.

\subsection{Political Institutions: Between Globalization and Europeanization}

Whether and how institutions are transformed because of globalization and Europeanization are the questions that normally appear first. Institutions have always been in the core of political studies and a variety of approaches, such as rational choice, organisation theory or sociological institutionalism and historical institutionalism, all gathered under the term new institutionalism, has been developed in order to analyse them (Hall and Taylor, 1996, Immergut, 1998). New institutionalism is interested in formal and informal structures and rules, change and stability and the role of agents within institutions. As Campbell (2004: 124-125) shows institutionalists have become interested in globalization and its effects on various fields such as corporate governance, welfare policies and taxation. As it has been already outlined new-institutionalism has also influenced the discussion on Europeanization (Risse, Green Cowles and Caporaso, 2001, Boerzel and Risse, 2003). Moving a step forward, the focus of this section is upon institutional change and globalization as well as Europeanization. Lowndes (1996: 194) argues that "change and stability are stages in an institutional lifecycle" but when does change take place and do the two phenomena direct change towards the same track? Do both of the phenomena have the same impact upon domestic institutions? 
Institutions are more likely to change when there is a combination of endogenous and exogenous pressures for reform. The endogenous pressures to change, or as Schmidt (2002) describes them, the national mediating factors to change, vary between EU member-states. For example, the policy legacy of Spain that was under a dictatorial regime is different to the policy legacy of the UK that has never experienced dictatorship. What is of interest to this paper is the exogenous factors which means globalization and Europeanization and the mechanisms that are in place and lead to specific outcomes such as convergence, divergence or inertia at the national level. Two types of institutions are usually considered to change: governance institutions and welfare state institutions. They are becoming more decentralised and more market-oriented. New Public Management (NPM) is the dominant mode of governance within EU member-states and as a result public institutions are privatized and independent authorities are created in order to regulate them (for example Hood, 1991, Ketti, 2000). Examples can be found all over Europe. The Anglo-Saxon countries are leading the reforms. Rhodes (1994) describes changes in the UK public services as the hollowing out of the state. The trend has spread in the Scandinavian countries, in Germany and France and more recently in the South of Europe (Hood, 1998, Menz, 2005). Welfare state institutions are also in a process of reform where one of the most important concerns is to maintain the international competitiveness of the state whatever the political choices upon size or redistribution are (Scharpf and Schmidt, 2000).

Are the mechanisms of Europeanization different to those of globalization in this process of liberalization and marketization of governance and welfare institutions? It can be argued that no substantial difference can be observed in the mechanisms of globalization and Europeanization. The only doubt is what comes first: the push from the EU or the push from global processes, which resembles the chicken and the egg question. 'Soft' mechanisms such as diffusion and mimesis are in place at a global level pushing forward institutions linked with NPM. The only mechanism that can be described as 'hard' is indirect coercion for EU member-states to adopt more efficient and more effective institutions in order for European integration to move forward. Not only the EU does not seem to put an obstacle to forces of globalization but even pushes member-states towards reform of their public sectors. The belief in the importance of sustaining a European Social Model distinct from the crude market-oriented model of globalization is what could possibly outline the difference between the two phenomena (e.g. Graziano, 2003). Antoniades (2007) eloquently summarises the debate by saying that some analysts claim that a distinctive European Social Model of capitalism exists while others see the discussion about the European Social Model as a way of buying support and creating consent in Western Europe in favour of the single market and EMU. Nevertheless, no concrete institutional examples that demonstrate a dominant European Social Model distinct from the global trend towards NPM can be offered. The next two sections explore whether these differences are more obvious at a policy or values-identities level.

\subsection{Public Policies Reforms}

The public policies of EU member-states and how they change is another way to assess the impact of globalization and Europeanization upon domestic politics. Does the impact of globalization differ to that of Europeanization? Policy change has always been one of the central themes of public policy analysis and the exogenous factors to change are a challenging question. The policy networks approach has been one of the most successful tools for analysing change because it turns the lens towards the 
interaction of all important agents within a given political system (Marsh and Rhodes, 1992). In particular, approaches such as the epistemic communities (Haas, 1992), the advocacy coalitions framework (Sabatier and Jenkins-Smith, 1997) and the policy transfer network (Evans and Davies, 1999) have proved to be most useful for the understanding of exogenous pressures because they investigate processes of learning and transfer which are in the heart of policy change and the way it is influenced by exogenous factors such as globalization and Europeanization (Ladi, 2005a).

What is not offered by any of these approaches is tools in order to distinguish the different impact of globalization and Europeanization. Does this happen because there is no real distinction or is there a gap in the literature? In order to answer this question two dimensions need to be explored: the substance of the policies and the decision-making and implementation processes of the policies. As far as it concerns the first dimension what can be easily observed is that both globalization and Europeanization favour neo-liberal policies that promote competitiveness and this is clearly reflected on EU member-states public policies (e.g. Cerny, 1996 and Korpi, 2003, Rosamond, 2002). Where there is a distinction is in the existence of an EU cohesion policy that through the use of structural funds gives the chance to weaker EU member-states to modernize and to stabilize without necessarily put into place market-oriented policies (Verdier and Breen, 2001, Tsoukalis 2003). For example, in the first period of EU regional policy, cohesion funding was going directly to Objective 1 regions without necessarily reinforcing specific changes. Nevertheless, the ultimate goal is still the competitiveness of the EU as a whole, and thus it can be argued that the nature of pressures coming to EU member-states from the two phenomena is not significantly different.

As far as the second dimension, is concerned, the processes of public policy, the trends promoted by globalization and Europeanization are again similar. NPM calls for open processes of decision-making and for the participation of non governmental organisations (NGOs) at all stages of the policy process (Rhodes, 1997). The same is true of the EU where again the formulation and implementation of policies involves a number of actors, including NGOs (Graziano, 2003). It is interesting to note, that there are always actors that do not participate in the negotiations and as a result policies can be blocked at the domestic or European level, as was the case with the European Constitution. In the next section, the values and identities and how they are expressed in the discourse of globalization and Europeanization is discussed in order to evaluate where and whether they differ.

\subsection{Values and Identities: Cosmopolitan and/or European identity?}

The third dimension that is explored in order to evaluate the relationship between Europeanization and globalization is that of values and identities. The focus this time is on agents of policy change and how their discourse, values and identities are changing. Can the changes that are taking place be described as a result of both globalization and Europeanization or are the two trends producing different results? Two terms that are often used and attempt to capture these collective identities are cosmopolitan identity and European identity. In this section the two terms are analysed and compared in order for some conclusions to be drawn.

Although the term cosmopolitan identity has been widely used not all theorists agree that we are actually moving towards a cosmopolitan identity and a common international value system. The sceptics and those that consider globalization to be mainly an economic activity dispute the existence of such a 
trend (e.g. Hirst and Thompson, 1999). In contrast, the supporters of globalization trace a trend for the creation of a cosmopolitan social democracy that has as its main values, global social justice, democracy, ecumenical human rights, human security, the rule of law and internationalist solidarity. They believe in the creation of "citizens of the world" (Held and McGrew, 2002). Mouzelis (2001) claims that cosmopolitanism is emerging and moves from the economic sphere, to the political, social and cultural spheres. In the political sphere, the values that tend to be globalized are democracy and the protection of human rights. In the social sphere, the impetus of neo-liberal globalization deepens social inequalities and drives to the realization of values such as global social solidarity that refers to the necessity of common action on issues such as poverty and the protection of the environment. Finally, in the cultural sphere, the most important value is the respect for cultural differences. A value that allows for the emergence of a new cosmopolitan identity that accepts the diversity of national identities, and leads to the existence of multiple identities. As it follows from the above discussion, the values that tend to be globalized do not originate from only one political tradition. The significance of neo-liberalism is obvious either as a positive push for values such as the respect of human rights, or as a reason for reactions and for the propulsion of balancing values such as the protection of the environment.

Given the close relationship of globalization and Europeanization in the reform of political institutions and public policies, it is expected that the above elements of cosmopolitan identity and of the global value system will be expressed with even more density and clarity within the EU framework. It is therefore claimed, that given that the EU is the most advanced regional organisation and is actually an organisation created by West-European countries, what is described by the terms European identity and European value system is similar to what is signified by the terms cosmopolitan identity and cosmopolitan value system. A number of writers follow this logic and demonstrate the globalization of European values and their transformation to global values (e.g. Norris, 2000). Furthermore, it is claimed that the European identity is strengthened due to globalization and to continuous integration (Herrmann and Brewer, 2004). The next step is to define European identity and to describe the European value system even though it is accepted that they are still in their making.

The term European identity similarly to the term cosmopolitan identity at a first glance is general and quite vague. Kontochristou (2004: 222) describes European identity as a special type of collective identity that "indicates acceptance of the basic values and principles of the EU, as well as a feeling of social coherence and of a common route". She is making a useful distinction between objective and subjective characteristics of European identity. The objective characteristics concern the presentation of European identity in the treaties and regulations of the EU, in its political institutions and in its basic values and principles, as for example in the Draft Treaty of the European Constitution. On the other hand, the subjective characteristics refer to the way people perceive this identity. Empirical evidence shows that the feeling of a common identity within the EU is still very low. For example, in 2000 according to the Eurobarometer only 22\% of EU member-states citizens expressed the feeling of a European identity (Kontochristou, 2003 and Norris, 2000). Nevertheless, it can be argued that because of the increase of a European identity feeling between the elites and their efforts and belief in the European project, a basic system of European values is emerging and is materialised within EU treaties and documents (Laffan, 2004, Wodak, 2004, Psarrou, 2005). A good example is the Draft Treaty establishing a Constitution for Europe. 
The most recent document where there is a reference to the European values is the Draft Treaty establishing a Constitution for Europe (European Convention, 2003). The first lines of the Preamble already mention the cultural, religious, and humanist inheritance of Europe and the global values of inviolable and inalienable human rights, freedom, democracy, equality and the rule of law. It is interesting to observe how the European and the global levels amalgamate. European values are lifted to the global level and then return to Europe through the Preamble of the European Constitution. In the third paragraph of the Preamble the global responsibility of Europe is proclaimed when it said that Europe has "to strive for peace, justice and solidarity throughout the world" (European Convention, 2003: 5). A final element that can be extracted from the Preamble is the recognition of the existence of multiple identities because European citizens remain proud of their national identities but at the same time are certain that their best options are in Europe "united in its diversity" (European Convention, 2003:5).

In brief, a connection between cosmopolitan and European identity and between cosmopolitan and European values can be observed which is particularly interesting because the EU is often considered to function as the protective mechanism of EU member-states against globalization. This is not surprising given that a concord exists in the political dimension of the European and global levels towards a neo-liberal value system that attempts to soften its negative impact by also adopting some elements of global transformation and of social democracy. Moreover, both cosmopolitan and European identities are to a large extent a creation of elites and they are complementing and not substituting for national and political identities that are deeply embedded and are significantly diversified. The most significant political values of both the global and European levels are democracy and the protection of human rights. At the social sphere, it is social solidarity and at the cultural level is the respect of diversity. The comparison between globalization and Europeanization demonstrates that even at the dimension of values and identities, no big differences exist.

\section{Conclusion}

Both globalization and Europeanization are multi-dimensional terms describing complex phenomena. A vast literature discussing them exists and all theoretical and political traditions have shown an interest in the two phenomena and their impact. This makes any attempt to frame and analyse them particularly demanding. One of the main difficulties of coming to a conclusion about the relationship between globalization and Europeanization is that a variety of tools and methodologies from across the social sciences are needed in order to analyse them. The purpose of this paper has been to discuss the relationship between globalization and Europeanization by focussing on the impact of the two phenomena upon EU member-states. The tentative conclusions that can drawn from the above analysis are that the two phenomena are interwoven and there is no antithetical relationship between the two. Their core is similar, based on the values of liberalization, representative democracy and open market economy. Diffusion is taking place in a similar way for both phenomena through the use of both 'soft' and 'hard' mechanisms and taking place at both the material and the ideational level. As a result their impact upon domestic politics is not easily distinguishable. 
A three-dimensional approach was applied in order to explore whether there is any significant difference in the impact of globalization and Europeanization upon EU member-states. The first dimension concerns political institutions and it was shown that the trend, irrespectively of globalization or Europeanization, is towards decentralisation, open market and institutions informed by the requirements of New Public Management (NPM). The conclusion was not that different on the second dimension which is public policy change. Both the substance of the policies and the decisionmaking and implementation processes put into practice NPM techniques and no clear distinction between the effect of globalization and Europeanization was observed. The third dimension that looked at values and identities showed, again, that there is significant overlap between cosmopolitan and European identities and values systems and that the one is informing the other. The idea of multiple identities and the respect of democracy, human rights, social solidarity and diversity have become central due to both globalization and Europeanization.

Further research is necessary in order to observe the impact of the two phenomena out of the EU but also in order to provide more detailed empirical case-studies that could reveal thin but significant differences about the effect of the two phenomena. Given the analysis and the evidence up to now, it can be argued that globalization and Europeanization have similar and sometimes revolutionary impact upon EU member-states. Institutions, policies, values and identities cannot be strictly domestic and they are influenced by a combination of strongly connected exogenous factors.

\section{References}

Anderson, James. 1995. The Exaggerated Death of the Nation-State. In James Anderson, Chris Brook and Allan Cochrane. A Global World? Re-ordering Political Space, pp. 65-106. Oxford: Oxford University Press and The Open University.

Antoniades, Andreas. 2007. Negotiating the Possible: a Perspective from Western Europe. In Paul Bowles et al. Regional Perspectives on Globalization: A Critical Reader. Basingstoke: Palgrave (in print).

Archer, Margaret. 1985. Structuration versus Morphogenesis. In Shmuel N. Eisenstadt and Horst J. Helle. Macro-Sociological Theory, Vol. 1, pp. 58-88. Newbery Park, CA: SAGE Publications.

Börzel, Tanja A., and Thomas Risse. 2003. Conceptualising the Domestic Impact of Europe. In Kevin Featherstone and Claudio Radaelli. The Politics of Europeanisation, pp. 55-78. Oxford: Oxford University Press.

Boerzel, Tanja. 1999. Towards Convergence in Europe? Institutional Adaptation to Europeanization in Germany and Spain. Journal of Common Market Studies, 37 (4): 573-596.

Callinicos, Alex. 2000. Equality. Cambridge: Polity Press.

Cerny, Phil. 1996. Globalization and Other Stories: The Search for a New Paradigm for International Relations. International Journal, 51 (4): 617-637.

Della Sala, Vincent. 2004. The Italian Model of Capitalism: On the Road between Globalization and Europeanization? Journal of European Public Policy, 11 (6): 1041-1057.

Dolowitz, David and David Marsh. 1996. Who Learns from Whom? Political Studies, XLVI: 343-357. 
Evans, Mark and Jonathan Davies. 1999. Understanding Policy Transfer: A Multi-level, Multidisciplinary Perspective. Public Administration, 77 (2): 361-386.

European Convention. 2003. Draft Treaty Establishing a Constitution for Europe.

Falk, Richard. 1995. On Humane Governance: Toward a New Global Politics. Cambridge: Polity Press.

Featherstone, Kevin. 2003. Introduction: In the Name of 'Europe'. In Kevin Featherstone and Claudio Radaelli. The Politics of Europeanization, pp. 3-26. Oxford: Oxford University Press.

Fukuyama, Francis. 1992. The End of History and the Last Man. New York: Free Press.

Giddens, Anthony. 1984. The Constitution of Society. Cambridge: Polity Press.

Gourevitch, Peter. 1978. The Second Image Reversed: The International Sources of Domestic Politics. International Organization, 32 (4): 881-912.

Graziano, Paolo. 2003. Europeanization or Globalization? Global Social Policy, 3 (2): 173-194.

Haas, Peter M. 1992. Introduction: Epistemic Communities and International Policy Coordination. International Organization, 46: 1-36.

Hall, Peter A. and Rosemary C. R. Taylor. 1996. Political Science and the Three New Institutionalisms. Political Studies, XLIV (5): 936-957.

Harman, Chris. 1996. Globalization: a Critique of New Orthodoxy. International Socialism, 73: 3-33.

Hay, Colin and David Marsh. 1999. Introduction: Towards a New (International) Political Economy? New Political Economy, 4 (1): 5-22.

Hayek, Friedrich. 1976. The Road to Serfdom. London: Routledge.

Held, David and Andrew Mc Grew. 2002. Globalization/Anti-Globalization. Cambridge: Polity Press.

Held, David et al. 1999. Global Transformations. Cambridge: Polity Press.

Held, David. 1996. Models of Democracy. Cambridge: Polity Press.

Held, David. 1991. Democracy and the Global System. In David Held. Political Theory Today, pp. 197235. Cambridge: Polity Press.

Herrmann, Richard and Marilynn B. Brewer. 2004. Identities and Institutions: Becoming European in the EU. In Richard Herrmann, Thomas Risse, and Marilynn Brewer. Transnational Identities, pp. 1-22. Lanham: Rowman and Littlefield Publishers.

Higgott, Richard. 1999. Economic, Politics and (International) Political Economy: The Need for a Balanced Diet in an Era of Globalization. New Political Economy, 4 (1): 24-36.

Hinsley, Francis H. 1986. Sovereignty. Cambridge: Cambridge University Press.

Hirst, Paul and Grahame Thompson. 1999. Globalization in Question: The International Economy and the Possibilities of Governance. Cambridge: Polity Press.

Hood, Chris. 1998. The Art of the State. Oxford: Oxford University Press.

Hood, Chris. 1991. A Public Management for All Seasons? Public Administration, 69: 3-19.

Immergut, Ellen. 1998. The Theoretical Core of the New Institutionalism. Politics and Society, 26 (1).

Jordana, Jacint, David Levi-Faur and Imma Puig. 2006. The Limits of Europeanization: Regulatory Reforms in the Spanish and Portuguese Telecommunications and Electricity Sectors. Governance, 19 (3): 437-464.

Kaul, Inge, Isabelle Gurnberg and Marc Stern. 1999. Global Public Goods: International Cooperation in the Twenty-First Century. Oxford: Oxford University Press.

Kegan, Paul and Kenichi Ohmae. 1990. The Borderless World. London: Collins.

Keohane, Robert O. and Helen Milner V. (eds). 1996. Internationalization and Domestic Politics. Cambridge: Cambridge University Press. 
Ketti, Donald. 2000. The Transformation of Governance: Globalization, Devolution, and the Role of Government. Public Administration Review, 60 (6): 488-497.

Klein, Naomi. 2000. No Logo. London: Flamingo.

Knill, Christoph. 2001. The Europeanisation of National Administrations. Cambridge: Cambridge University Press.

Kontochristou, Maria. 2004. The Role of Public and Private Mass Media in the Creation of a European Identity. Review of Public Administration, 10: 219-243 (in Greek).

Kontochristou, Maria. 2003. The Role of Greek Television in Constructing a European Identity. London: London School of Economics and Political Science, European Institute.

Korpi, Walter. 2003. Welfare-State Regress in Western Europe: Politics, Institutions, Globalization and Europeanization. Annual Review of Sociology, 29: 589-609.

Ladi, Stella. 2006. Globalization, European Identity and Mass Media: The Cases of Greece and Spain. In Maria Kontochristou Mass Media and Identity in Greece. Athens: Papazisis. (in press, in Greek).

Ladi, Stella. 2005a. Globalization, Policy Transfer and Policy Research Instritutes. Cheltenham: Edward Elgar.

Ladi, Stella. 2005b. Europeanization and Environmental Policy Change. Policy and Society, 24 (2): 1-15.

Ladrech, Robert. 1994. Europeanization of Domestic Politics and Institutions: The Case of France. Journal of Common Market Studies, 32 (1): 69-88.

Laffan, Brigid. 2004. The European Union and Its Institutions as 'Identity Builders'. In Richard Herrmann, Thomas Risse, and Marilynn Brewer. Transnational Identities, pp. 75-96. Lanham: Rowman and Littlefield Publishers.

Leftwich, Andrew. 2000. States of Development. Cambridge: Polity Press.

Leibfried, Stephan. 2000. National Welfare States, European Integration and Globalization: A Perspective for the Next Century. Social Policy and Administration, 34 (1): 44-63.

Levi-Faur, David. 2004. On the 'Net Impact' of Europeanization: The EU's Telecoms and Electricity Regimes Between the Global and the National. Comparative Political Studies, 37 (1): 3-29.

Lowndes, Vivien. 1996. Varieties of New Institutionalism: A Critical Appraisal. Public Administration, 74: 181-197.

Marsh, David and Rod Rhodes. 1992. Policy Networks in British Government. Oxford: Clarendon Press.

Menz, Georg. 2005. Auf Wierdersehen, Rhineland model: Embedding neoliberalism in Germany. In Susanne Soederberg et al. Internalizing globalisation. Basingstoke: Palgrave

Mouzelis, Nikos. 2001. "Cosmopolitanism: The Globalization of Values." Presentation at the International Symposium Rethinking Civilisation. Ministry of Culture, Hellenic Culture Organization S. A., Cultural Olympiad 2001-2004: 95-100 (in Greek).

Mouzelis, Nikos. 1995. Sociological Theory: What Went Wrong? London and New York: Routledge.

Norris, Pipa. 2000. Global Governance and Cosmopolitan Citizens. In J. S. Nye and J. D. Donahue. Governance in a Globalizing World. Washington D.C.: Brookings Institution Press.

Page, Edward. 2003. Europeanization and the Persistence of Administrative Systems. In Jack Hayward and Anand Menon. Governing Europe, pp. 162-176. Oxford: Oxford University Press.

Psarrou, ?elli. 2005. The Influence of Nationalism in the Political Integration of Europe. Greek Political Science Review, 25: 107-136 (in Greek).

Radaelli, Claudio. 2003. The Europeanization of Public Policy. In Kevin Featherstone and Claudio Radaelli. The Politics of Europeanization, pp. 27-56. Oxford: Oxford University Press. 
Risse, Thomas, Maria Green Cowles and James Caporaso. 2001. Europeanization and Domestic Change: Introduction. In Maria Green Cowles, James A. Caporaso, and Thomas Risse. Europeanization and Domestic Change, pp.1-20. New York: Ithaca.

Rosamond, Ben. 2002. Imagining the European Economy: 'Competitiveness' and the Social Construction of 'Europe' as an Economic Space. New Political Economy, 7 (2): 157-177.

Rosamond, Ben. 1999. Discourses of Globalization and the Social Construction of European Identities. Journal of European Public Policy, 6 (4): 652-668.

Rhodes, Rod. 1997. Understanding Governance - Policy Networks, Reflexivity and Accountability. Maidenhead: Open University Press.

Sabatier, Paul and Hank Jenkins-Smith. 1999. The Advocacy Coalition Framework: An Assessment. In Paul Sabatier.Theories of the Policy Process, pp. 117-166. Boulder, C0: Westview.

Scharpf, Fritz W. 2002. The European Social Model: Coping with the Challenges of Diversity. Journal of Common Market Studies, 40 (4): 645-670.

Scharpf, Fritz W. and Vivien A. Schmidt. 2000. Conclusions. In Scharpf, Fritz W. and Vivien A. Schmidt. Welfare and Work in the Open Economy, pp. 310-336. Oxford: Oxford University Press.

Scholte, Jan A. 2005. Globalization. Basingstoke and New York: Palgrave Macmillan.

Schmidt, Vivien. 2002. Europeanization and the Mechanics of Economic Policy Adjustement. Journal of European Public Policy, 9 (6): 894-912.

Strange, Susan. 1996. The Retreat of the State. Cambridge: Cambridge University Press.

Tsoukalis, Loukas. 2003. What Kind of Europe? Oxford: Oxford University Press.

Verdier, Daniel and Richard Breen. 2001. Europeanization and Globalization: Politics Against Markets in the European Union. Comparative Political Studies, 34 (3): 227-262.

Wallace, Helen. 2000. Europeanisation and Globalisation: Complementary or Contradictory Trends? New Political Economy, 5 (3): 369-382.

Wincott, Daniel. 1999. Globalization and European Integration. In Colin Hay and David Marsh. Demystifying Globalization, pp. 168-190. London: Macmillan.

Wodak, Ruth. 2004. National and Transnational Identities: European and Other Identities Constructed in Interviews with EU Officials. In Richard Herrmann, Thomas Risse, and Marilynn Brewer. 